\title{
Raptors of the Izdrevaya River Basin, Russia
}

\section{ПЕРНАТЫЕ ХИЩНИКИ БАССЕЙНА РЕКИ ИЗДРЕВАЯ, РОССИЯ}

\author{
Nikolenko E.G. (Sibecocenter LLC, Novosibirsk, Russia), \\ Shtol D.A. (Russian Raptor Research and Conservation Network, Novosibirsk, Russia), \\ Karyakin I.V. (Center of Field Studies, N. Novgorod, Russia) \\ Николенко Э.Г. (ООО «Сибэкоцентр», Новосибирск, Россия), \\ Штоль Д.А. (Российская сеть изучения и охраны пернатых хищников, Новосибирск, \\ Россия), \\ Карякин И.В. (Центр полевых исследований, Н. Новгород, Россия)
}

\section{Контакт:}

Эмьвира Николенко ООО "Сибэкоцентр" 630090, Россия,

Новосибирск, а/я 547 тел.: +79231501279 elvira_nikolenko@mail.ru www.sibecocentr.ru www.rrren.ru

\section{$\triangle$ митрий Штоль}

Российская сеть изучения и охраны пернатых хишников 630090, Россия,

Новосибирск,

ул. Акацемическая, 8-19 тел.: +7913 3952900 d.shtol@gmail.com

Игорь Карякин

Центр полевых иссие-

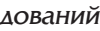

603109, Россия,

Нижний Новгород,

ул. Нижегородская, 3-29

тел.: +7831433 3847

ikar_research@mail.ru

\section{Резюме}

В статье обобшены результаты эпизодических выездов авторов в бассейн Издревой в 2012-2016 гг. Основными целями этих выезАов были: выяснение видового состава гнездовой фауны пернатых хищников, определение характера распределения гнездяшихся пар и проектирование системы искусственных гнездовий для разных видов соколообразных и сов. В бассейне р. Издревой выявлено пребывание 8 видов соколообразных, мяя 4 из которых установлено гнездование, и 3 вида сов, мяя двух из которых установлено гнездование. Максимальная плотность распределения в бассейне р. Издревой определена для чёрного коршуна (Milvus migrans) - 51,83 ос./100 км² (n=93). Второй по численности после коршуна вид хищных птиц - канюк (Вutео buteo), его плотность распределения составила 8,88 ос./100 км² общей площади. Алиннохвостая неясыть (Strix uralensis), встреченная в 2012 г. мишь на Авух участках, в результате проведения биотехнических мероприятий, заселила 4 гнездовых ящика в 2013 г., а к 2016 г. увеличила численность до 8 пар, успешно размножаюшихся в совятниках. Выявлены основные негативные фракторы для хишных птиц в бассейне Издревой: гибель на АЭП в результате поражения электротоком, нелегальные рубки, нелегальное строительство $а м б$, строительство мусоросортировочного комбината (МСК) с полигоном твёрдых коммунальных отходов.

Киючевые слова: хишные птицы, пернатые хишники, чёрный коршун, Milvus migrans, канюк, Buteo buteo, мииннохвостая неясыть, Strix uralensis, Изаревая.

Поступила в редакцию: 10.12.2016 г. Принята к публикации: 01.04 .2017 г.

\section{Abstract}

This article compiles the results of episodic visits of the aurhoes to the basin of the Izdrevaya river during 2012 2016. The main goals of those visits were: to figure out the species composition of nesting fauna of birds of prey, estabishing the manner of nesting pairs' distribution and designing a system of nestboxes for different species of birds of prey and owls. 8 species of Falconiformes are present in the Izdrevaya river basin, 4 of which are nesting, and 3 species of Strigiformes, 2 of which are nesting. The Black Kite (Milvus migrans) has maximum density in the Izdrevaya river basin -51.83 ind./100 $\mathrm{km}^{2}(n=93)$. The Common Buzzard (Buteo buteo) is the second in number after the Black Kite, its density being $8.88 \mathrm{ind} / 100 \mathrm{~km}^{2}$ of the total area. The Ural Owl (Strix uralensis), encountered only on two territories in 2012, inhabited 4 nestboxes in 2013 as the result of biotechnical measures taken, and its number increased to 8 pairs successfully breeding in the nextboxes in 2016. Main negative factors for birds of prey in the Izdrevaya river basin were established: electrocution on power lines, illegal logging, illegal construction of dams and the construction of waste-sorting plant with a range of solid municipal waste.

Keywords: birds of prey, raptors, Black Kite, Milvus migrans, Common Buzzard, Buteo buteo, Ural Owl, Strix uralensis, Izdrevaya.

Received: 10/12/2016. Accepted: 01/04/2017

DOI: $10.19074 / 1814-8654-2017-34-74-82$

\section{Введение}

Изучение хишных птиц в бассейне реки Изаревая проводилось в рамках комплексной работы инициативной группы «Поможем реке Издревая" по созданию экспериментального полигона мия реамизации устойчивого природопользования. Эта работа с 2003 по 2014 гг. реаиизовывамась в рамках одноимённой благотворительной программы МБОО «Сибирский экологический центр", а с 2015 г. продолжена инициативной группой самостоятельно. В 2009 г. в рамках Аанной работы в бассейне Изаревой был создан памятник природы
The basin of the Izdrevaya river is situated to the east of major metropolis - Novosibirsk, $8 \mathrm{~km}$ away from the west border of the city. Izdrevaya is the left tributary of Inya river, which in turn flows to $\mathrm{Ob}$ within the city limits. The length of Izdrevaya is about $27 \mathrm{~km}$, the width of its basin from north to south makes $20 \mathrm{~km}$ and from west to east - 10-12 km.

There are 50 dacha communities (gardens) situated in Izdrevaya valley, as well as 4 villages and some skiing bases, and there are regular tourist activities.

The work on studying the species compo- 


\section{Contact:}

Elvira Nikolenko

Sibecocenter, LLC

P.O. Box 547 ,

Novosibirsk

Russia, 630090

tel.: +79231501279

elvira_nikolenko@mail.ru

www.sibecocentr.ru

www.rrren.ru

Dmitry Shtol

Russian Raptor Research and Conservation

Network

Akademicheskaya str.

8-19

Novosibirsk,

Russia, 630090

tel.: +79133952900

d.shtol@gmail.com

\section{Igor Karyakin}

Center of Field Studies

Nizhegorodskaya str.,

3-29

Nizhniy Novgorod

Russia, 603109

tel.: +7831433 3847

ikar_research@mail.ru регионаиьного значения плошацью 70,68 га "Аолина реки Издревая", а в 2016 г. разработано эколого-экономическое обоснование киастерного ООПТ в бассейне р. Изаревая. Несмотря на это, в 2016 г. амминистрацией Новосибирской области подписано концессионное соглашение с ООО “Экология-Новосибирск" о строительстве в бассейне Издревой мусоросортировочного комбината (МСК) с полигоном твёрдых коммунальных отходов (ТКО), которое перечёркивает все предыдушие усилия, как обшественности, так и самой амминистрации области, по сохранению природного наследия Аанной территории и её развития в качестве экспериментацьного полигона м^я реализации устойчивого природопользования. В связи с этим актуамьна публикация первичных данных о распространении, характере распределения и численности хишных птиц в бассйене р. Изаревой до момента появления на Аанной территории новой антропогенной угрозы их сушествованию.

Аанная статья обобшает результаты эпизодических выездов авторов в бассейн ИзАревой в 2012-2016 гг., одними из основных целей которых были выяснение виАового состава гнездовой фауны пернатых хишников, определение характера распределения гнездяшихся пар и проектирование системы искусственных гнездовий мия разных видов соколообразных и сов.

\section{Район исследований}

Бассейн реки Издревая расположен на восток от крупного мегаполиса - г. Новосибирска, в 8 км от запацной границы города. Изаревая является левым притоком реки Иня, которая, в свою очередь, впадает в Обь в черте города Новосибирска. Протяжённость Изаревой составляет око^о 27 км, её бассейн с севера на юг со- sition of birds of prey from the Izdrevaya river basin were performed on the $8^{\text {th }}-9^{\text {th }}$ of May, the $18^{\text {th }}-19^{\text {th }}$ of July and the $10^{\text {th }}$ $14^{\text {th }}$ of August 2012, and episodic visits also took place in 2013-2016. The total length of accounting car routes was 155.44 $\mathrm{km}$, pedestrian routes - about $42 \mathrm{~km}$. There were 40 forest edge territories with total length of $18 \mathrm{~km}$ examined during pedestrian routes to find nests of Accipitridae and owls. There was a targeted inspection of 20 forest territories suitable for nesting of Accipitridae, including areas of planted forest with total length of pedestrian routes of $9 \mathrm{~km}$.

All raptors were registered on car routes on unlimited zone with fixing the distance of detection at the moment of the first encounter. The accounting area was identified by the average distance of detection along the routes.

The area of the basin for the goals of the article was identified at $219.6 \mathrm{~km}^{2}$ including the Tigalikha river which flows into Inya, without populated areas and dacha communities - $200.9 \mathrm{~km}^{2}$ (fig. 1).

The accounting hasn't been performed in 2013-2016, but the checkout of nestboxes has been carried out and there were observations of birds of prey.

\section{The results of the research \\ Order Falconiformes}

There were 8 species discovered in the Izdrevaya river basin, 3 of which were breeding.

\section{Family Accipitridae}

Black Kite (Milvus migrans). The most common species of the Izdrevaya basin which is spread over the whole inspected territory.

Nests of 7 pairs of Black Kites were found on the territory of the Izdrevaya basin on the $9^{\text {th }}$ of May, 2012 on parts of forested ravines
Типичный мандшаст бассейна р. Издревая. Фото И. Карякина.

Typical landscape of the Izdrevaya river basin. Photo by I. Karyakin.

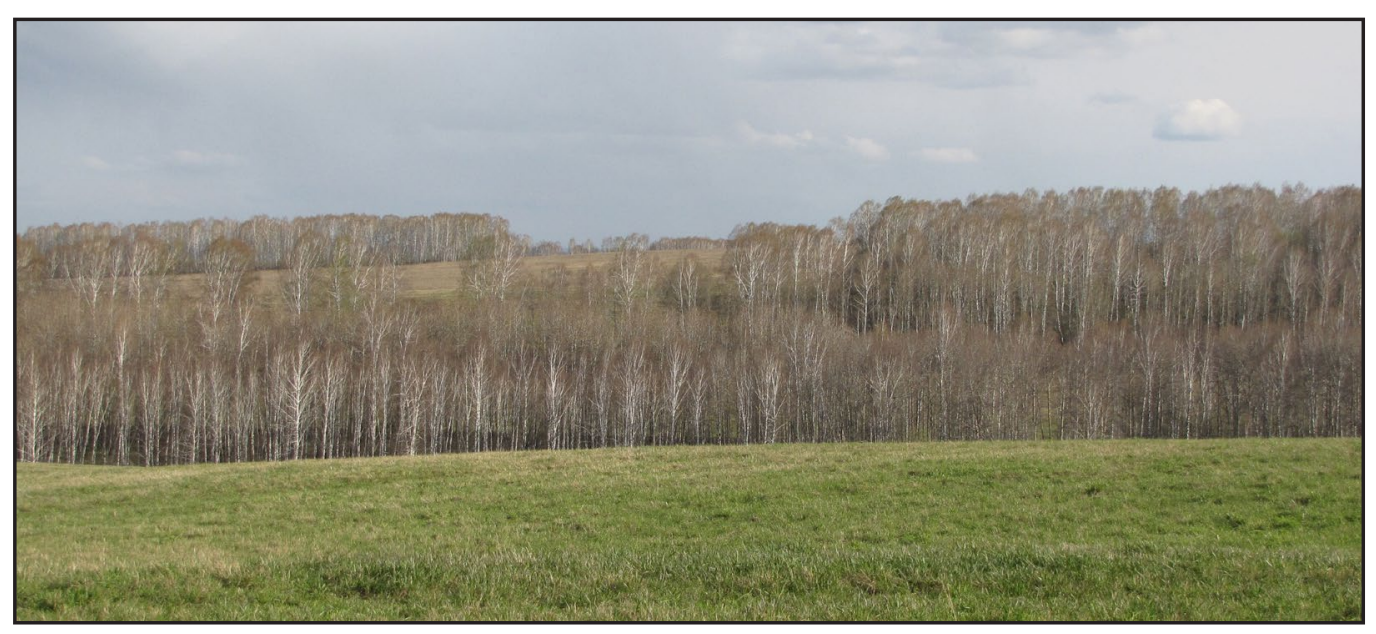


ставляет около 20 км, а с запада на восток - от 10 Ао 12 км.

Геоморфологически бассейн Изаревой расположен на стыке Запацно-Сибирской равнины и предгорий Алтае-Саянской горной области. Такое пограничное поможение предопределило интересный рельеср территории, в котором преобладают эрозионные формы в виде сложной, разветвлённой и глубоко врезанной системы логов и балок, но также прослеживаются и линии тектонических разломов, опредемяюшие простирание русел некоторых ручьёв. В геологическом отношении территория водосборного бассейна перекрыта с поверхности мошным плашом рыхлых четвертичных отложений, представленных лессовидными суглинками субаэрального генезиса. В нижнем течении река Издревая полностью пропиливает четвертичные отложения, обнажая по бортам и Анишу русла скаиьные палеозойские породы, но на большей территории русло реки и её притоков проложены в суглинистой толше.

По природному районированию Новосибирской области территория бассейна относится к правобережному лесостепному Приобью, предполагаюшему распространение естественно-фрагментированных ландшастов из сочетания перелесков, образованных травяными мелколиственными лесами и открытых, безлесных пространств, занятых луговыми сообшествами.

Территория Аавно и разнообразно освоена человеком. Все плоские водораз дельные пространства были распаханы в разное время под сельскохозяйственные угодья. Большая часть этих земель в настояшее время представлена залежами различного возраста, часть из которых зарастает лесом. Территория бассейна пересекается с севера на юг железнодорожной веткой межобластного значения; с запала на восток примерно в центральной части бассейн рассечён федеральной автомобильной трассой; в разных направлениях бассейн пересекают несколько высоковольтных миний электропередачи. В 2013 г. по границе бассейна (водоразделу рек Издревая и Переборка) начато строительство крупной автомобильной магистали (восточного объезАа г. Новосибирск).

В Аолине Изаревой расположено 50 Аачных обшеств (салово-некоммерческих товаришеств, дамее (НT), а также четыре посёлка, расположены горнолыжные базы, проводятся регулярные туристические мероприятия. which were thoroughly inspected. On the $19^{\text {th }}$ of July 20123 broods were observed, 27 birds in 19 spots were observed during car routes on the $9^{\text {th }}$ of May and on the $19^{\text {th }}$ of July 2012. One inhabited Black Kite nest was found in the floodplain of the Izdrevaya river in the lower course $1.3 \mathrm{~km}$ away from the estuary on the $12^{\text {th }}$ of July 2015 .

The distance between active nests of the Black Kite varied within the range from 0.8 to $2.2 \mathrm{~km}$ averaging at $(n=6) 1.24 \pm 0.51 \mathrm{~km}$.

The density of Black Kites in the Izdrevaya basin was 12.26 (pairs) $/ 100 \mathrm{~km}^{2}$ of the total area and 45.38 (pairs) $/ 100 \mathrm{~km}^{2}$ of forest area according to the sum of observations in May and July in $2012(n=22)$. The density of Black Kites including those registered in gatherings on outskirts of dacha communities and dumpsites was 51.83 ind./100 km² $(n=93)$.

Hen Harrier (Circus cyaneus). Rare and possibly breeding species of territory under examination. Wasn't observed in 2012. An adult male was observed on 03/05/2015 between Tokalikha and Malaya Izdrevaya rivers. The female was observed on 02/05/2016 on the watershed of Izdrevaya and Malaya Izdrevaya near Gusinyi Brod (Zaeva, 2016).

Pallid Harrier (Circus macrourus). Rare and possibly breeding species of the Izdrevaya river basin. An adult male was observed on 03/05/2015 between Tokalikha and Malaya Izdrevaya rivers.

Northern Goshawk (Accipiter gentilis). The breeding is possible, but the adult birds were observed in the examined part of the Izdrevaya basin only twice - on the $9^{\text {th }}$ of May, 2012 in the valley of Inya and on the $3^{\text {rd }}$ of May 2015 on the watershed in middle course of Malaya Izdrevaya.

Eurasian Sparrowhawk (Accipiter nisus). Uncommon breeding species. Spread over the territory of the Izdrevaya basin and nests both in river valleys and on watershed but never reaches high numbers.

Nests of two pairs were found on the $9^{\text {th }}$ of May 2012 in middle and upper course of the Izdrevaya river and hunting birds were observed in 5 more spots. Adult birds were observed in 2 more spots on the $3^{\text {rd }}$ of May 2015. Density was 2.96 (pairs)/100 km² of total area as the result of accounting territorial encounters, 3.81 ind./100 $\mathrm{km}^{2}$ of total area as the result of accounting all birds observed.

Common Buzzard (Buteo buteo). The second species in number after the Black Kite which nests in Izdrevaya basin. 


\section{Методика исследований}

Наиболее результативные работы по изучению видового состава хишных птиц бассейна Изаревой были проведены 8-9 мая, 18-19 июля и 10-14 августа 2012 г. Обшая протяжённость учётных автомобильных маршрутов составила 155,44 км, пеших - около 42 км. В ходе пеших выходов было осмотрено 40 опушечных участков на предмет гнездования ястребиных хищников и сов обшей протяжённостью 18 км. Целевым образом было осмотрено 20 участков леса, пригодных мия гнездования ястребиных, включая посахки леса, обшей протяжённостью пеших маршрутов - 9 км.

На автомобильных маршрутах регистрироваяи всех пернатых хишников на неограниченной полосе. Результаты этих учётов можно использовать мия получения оценок относительной численности встреченных видов, однако основной целью выездов являлась локаяизация гнездовых участков хишных птиц. Так как Аетаиьных площадочных учётов не проводилось, Аанные учётов можно считать предварительными. Птицы регистрироваяись во время автомаршрутов и пеших выходов с сриксированием Аамьности обнаружения $\Delta$ них в момент первой встречи. Учётная площаць определялась по средней Аальности обнаружения и протяжённости маршрутов.

Плошаль бассейна мия целей статьи с учётом р. Тигаииха, впацаюшей в Иню, определена в 219,6 км², за вычетом населённых пунктов и сацовых товаришеств 200,9 км² (рис. 1).

В 2013-2016 гг. учёты не проводились, но осушествлялась проверка искусственных гнезАовий и отмечамись встречи с пернатыми хишниками.

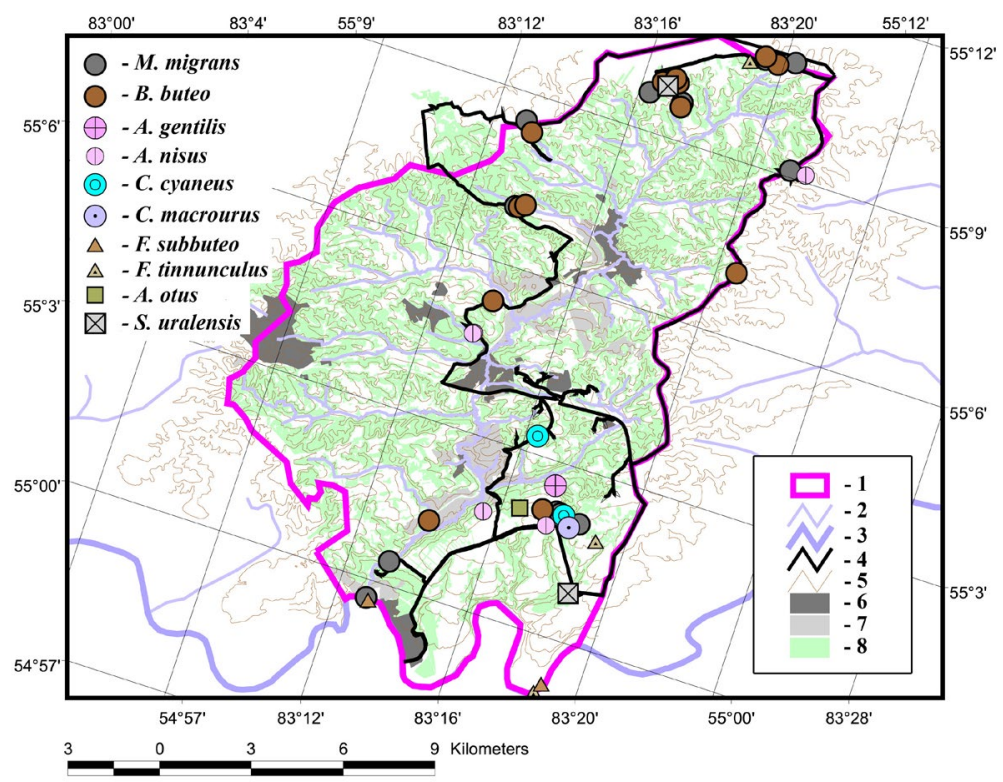

Five breeding territories of the Common Buzzard with living nests were discovered during the accounting on the $9^{\text {th }}$ of May and on the $19^{\text {th }}$ of July, 3 broods were observed and hunting birds were encountered on 5 more spots. Density was 5.50 (pairs) $/ 100$ km² $^{2}$ of total area as the result of accounting territorial encounters, 8.88 ind./100 $\mathrm{km}^{2}$ of total area as the result of accounting all birds observed.

\section{Family Falconidae}

Eurasian Hobby (Falco subbuteo). Rare possibly breeding species.

Single birds were observed in upper reaches of the Izdrevaya river on the $19^{\text {th }}$ of July 2012 and in the estuary of Izdrevaya on the $12^{\text {th }}$ of July 2015 . The Hobby also was observed on 01/09/2016 in the floodplain of the Inya river $6.2 \mathrm{~km}$ from the estuary of Izdrevaya upstream (Sukhov, 2016a). Above Izdrevaya village along the Inya river the Hobby normally nests in terrace pine forests.

Common Kestrel (Falco tinnunculus). Rare possibly nesting species.

Single birds were encountered in 3 spots in upper reaches of the Izdrevaya river in 2012. Density was 1.27 ind $/ 100 \mathrm{~km}^{2}$ of total area. Two Kestrels $1 \mathrm{~km}$ away from each other were observed on 03/05/2015 in upper reaches of Tokalikha. A photo of Kestrel was taken on the river Inya 6.2 $\mathrm{km}$ away from the estuary of Izdrevaya on 13/08/2016 (Sukhov, 2016b).

\section{Order Strigiformes \\ Family Strigidae}

Three species of owls were found in the Izdrevaya river basin, two of which were breeding.

Short-Eared Owl (Asio flammeus). Uncommon possibly breeding species, associated with meadows where it nests on the ground. Owls were encountered at

Рис. 1. Карта бассейна р. Издревая и точки регистраций территориаиьных пернатых хищников, приравненных к гнездовым. Условные обозначения: 1 - граница бассейна р. Издревая, 2 - малая река, 3 - большая река, 4 - автомобимьный маршрут, 5 - изогипсы, 6 - населённые пункты, 7 - сацовые товаришества, 8 - лес.

Fig. 1. The map of the Izdrevaya river basin and records of the territorial raptors, equated to breeding territories. Legend: 1 - the border of the Izdrevaya river basin, 2 - small river, 3 - large river, 4 - vehicular route on which raptors were accounted, 5 - isohypses, 6 - settlements, 7 -summer cottages and gardens, 8 - forest. 
Типичное гнездо коршуна в бассейне р. Изаревая. Фото И. Карякина

Typical nest of the Black Kite in the Izdrevaya river basin. Photos by I. Karyakin.

\section{Результаты исследований}

Отряд Соколообразные Falconiformes

В бассейне р. Изаревой выявлено пребывание 8 видов, ммя 3 из которых установлено гнездование.

\section{Семейство Ястребиные Accipitridae}

Чёрный коршун (Milvus migrans). Фоновый вид бассейна ИзАревой, который распрелелён по всей изучаемой территории.

Коршун является синантропным видом г. Новосибирска, а около свалок формирует концентрированные гнездовые поселения численностью из нескольких Аесятков пар, дистанция межАу гнёздами в которых составляет от нескольких Аесятков $А$ нескольких сотен метров. В частности, самое крупное ближайшее к Издревой гнезАовое поселение коршунов, сосредоточено близ Раздольненского полигона бытовых отхоАов в 2-х км к запалу от с. Раздольное к северу от Гусинобродского шоссе - здесь найдено 6 занятых гнёзд на участке 300 м и встречено 76 птиц. ОАнако в бассейне Издревой подобных поселений коршуна не выявлено, несмотря на то, что территория изобилует Аачными сообшествами.

На территории бассейна Издревой 9 мая 2012 г. найдены гнёзда 7 пар коршунов на участках облесённых логов, которые были детально обследованы, 19 июля 2012 г. встречены 3 выводка, также 27 птиц в 19 точках наблюдаиись на автомобильных маршрутах 9 мая и 19 июля 2012 г. Одно занятое гнездо коршуна было найдено в пойме Изаревой, в её нижнем течении, в 1,3 км от устья реки 12 июля 2015 г.

$\Delta$ истанция между занятыми гнёздами варьировала в пределах 0,8-2,2 км, составив в среднем $(n=6) 1,24 \pm 0,51 \mathrm{kм}$. night from the $18^{\text {th }}$ to $19^{\text {th }}$ of July 2012 on 3 spots along the $18.49 \mathrm{~km}$ route on the road among abandoned farmlands on the eastern border of the Izdrevaya river basin. Density of owls was 1.62 ind./10 km of the route.

Long-Eared Owl (Asio otus). Uncommon breeding species of forest habitat. Species specialized on feeding on voles (Microtus sp.) whose number dynamics influences the number dynamics of owls.

The only nest with incubating bird on the edge of forest was found along the Malaya Izdrevaya river and 2 individuals were encountered in two different spots on the $18^{\text {th }}$ of July 2012 and 2015. Density according to the accounting in forest edges was 5.56 pairs/100 km²,

Ural Owl (Strix uralensis). Uncommon breeding species, the number of which began to grow only after taking the measures on attracting the birds to nest in nestboxes.

During the targeted observation of the territory for the Ural Owl a single birds was found on watershed in upper reaches of the Izdrevaya river near Barlacksky village, a sitting spot of another owl was found in forest area on the left bank of the Tokalikha river $1.6 \mathrm{~km}$ away from the Inya river.

Due to biotechnical measures performed since 2012 (see article on page 27) the number of the Ural Owl breeding in nestboxes in the Izdrevaya river basin grew from 4 breeding pairs in 2013 (the next year after establishing the first nestboxes) to 8 breeding pairs in 2016. In 2016 distances between active nests of the Ural owl in nestboxes varied within 1.64-6.25 km, averaging $(n=7) 2.75 \pm 1.64 \mathrm{~km}$.

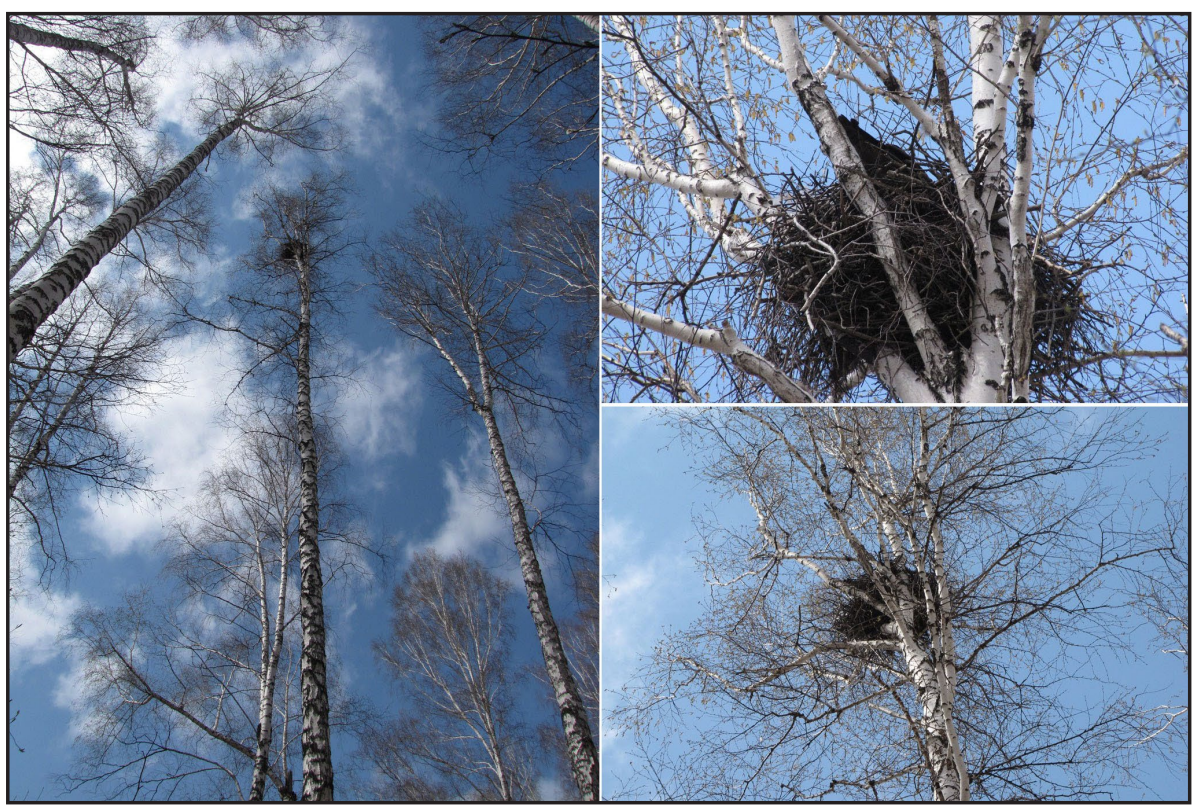

\section{Dangers and measures of protection}

From the most of dangers for birds of prey discovered in the Izdrevaya river basin we can specify the following:

1. Transmission lines dangerous for birds - 3 branches of $10-35 \mathrm{kV}$ power lines with pin insulators.

\section{Illegal logging \\ 3. Illegal construction of dams}

4. Project of waste sorting plant with a range of solid municipal waste construction.

The territory of the Izdrevaya river basin is characterized by disturbed faunistic complex of 
Чёрный коршун (Milvus migrans). Фото И. Карякина. Black Kite (Milvus migrans). Photo by I. Karyakin.

Средняя даиьность обнаружения коршунов на учётных маршрутах составила 0,58 км, ширина учётной полосы - 1,15 км, общая учётная плошахь - 179,44 км², лесная учётная плошахь - 48,48 км². Плотность распределения коршунов в бассейне Издревой (здесь мы приравниваем встречи к парам) составила 12,26 (пар)/100 км² обшей плошали и 45,38 (пар)/100 км² лесной площахи по сумме майских и июльских встреч в 2012 г. $(n=22)$. Плотность распределения коршунов с учётом регистраций в скоплениях на окраинах сацовых товаришеств и сваиок, которые впрочем могут относиться к птицам с ближайших гнездовых участков, составияа 51,83 ос./100 км² $(n=93)$.

Полевой лунь (Circus cyaneus). РеАкий, вероятно гнездяшийся вид исслеууемой территории. В 2012 г. не наблюдался. Взрослый самец встречен 03.05.2015 г. между реками Токамиха и Малая Издревая. Самка наблюдалась 02.05.2016 г. на водоразделе рек Маяая Издревая и Издревая близ Гусиного Брода (Заева, 2016).

Степной мунь (Circus macrourus). РеАкий, вероятно гнездяшийся вид бассейна Издревой. Взрослый самец был встречен на водоразделе рек Малая Издревая и Токамиха 3 мая 2015 г.

Тетеревятник (Accipiter gentilis). ГнезАование вполне вероятно, однако в обслеАованной части бассейна Издревой взрос-

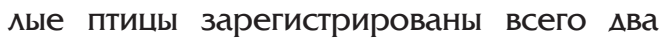
раза - 9 мая 2012 г. в долине Ини и 3 мая 2015 г. на водоразделе в среднем течении Малой ИзАревой.

Аостаточная кормовая база в виде тетеревиных птиц на большей части бассейна ИзАревой отсутствует, в связи с чем, стабильное гнездование вида можно ожидать Аишь в окрестностях мест концентрации сизых голубей (Columba livia) и врановых (Corvus sp.), которыми в районе исследований являются ^ишь свалки, а также мелькомбинаты и зернохранилиша в населённых пунктах.

Перепелятник (Accipiter nisus). Heмногочисленный гнездяшийся вид. Распространён по всей территории бассейна Издревой и гнездится как в Аолинах рек, так и на водоразделах, но высокой численности нигде не Аостигает.

Гнёзда Авух пар найдены 9 мая 2012 г. в среднем и верхнем течении реки Издревая, и ешё в 5 точках встречены охотяшие-

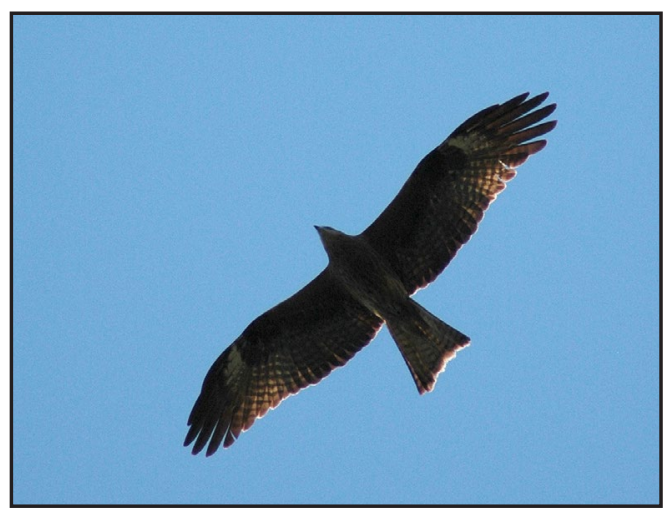

raptors, which almost completely excluded all specialized entomophage species (Honey Buzzard Pernis apivorus, Scops Owl Otus scops, Red-Footed Falcon Falco veapertinus), hollow nesting species (Aegolius funereus, Glaucidium passerinum), miophages specializing on catching prey species in low herbage (Harriers, Kestrel), the number of specialized miophages (Long-Eared Owl) and ornitophages (Goshawk, Sparrowhawk) who feed on 1-2 dominant species is extremely low. The existence and growth of the Ural Owl population is maintained due to realization of measures on the installation of nestboxes.

It's clear that this situation in the Izdrevaya river basin established because of the longterm influence of a range of factors, which caused a complex of native species to degrade, but some species with wider requirements for the feeding base, hunting and nesting biotopes (for example, the Common Buzzard) adapted to constant influence of those constant factors, and other species (Black Kite) even could make profit out of it and increased their local population numbers.

Considering this, the basin of the Izdrevaya river can be considered a universal range for studying mutual influence of vital activity of human and raptors, as well as for implementation of programs aimed on restoring the number of raptors in conditions of multidirectional anthropogenic pressure.

At the moment some of the most important directions for restoring the number of raptors in the Izdrevaya river basin are:

- Cancellation of waste sorting plant with a range of solid municipal waste construction;

- Design and creation of protected areas;

- Neutralizing the constant negative factors such as electrocution;

- Elimination of limiting factors such as lack of places for nesting and continuation of measures aimed on attracting raptors to breeding in artificial nests. 


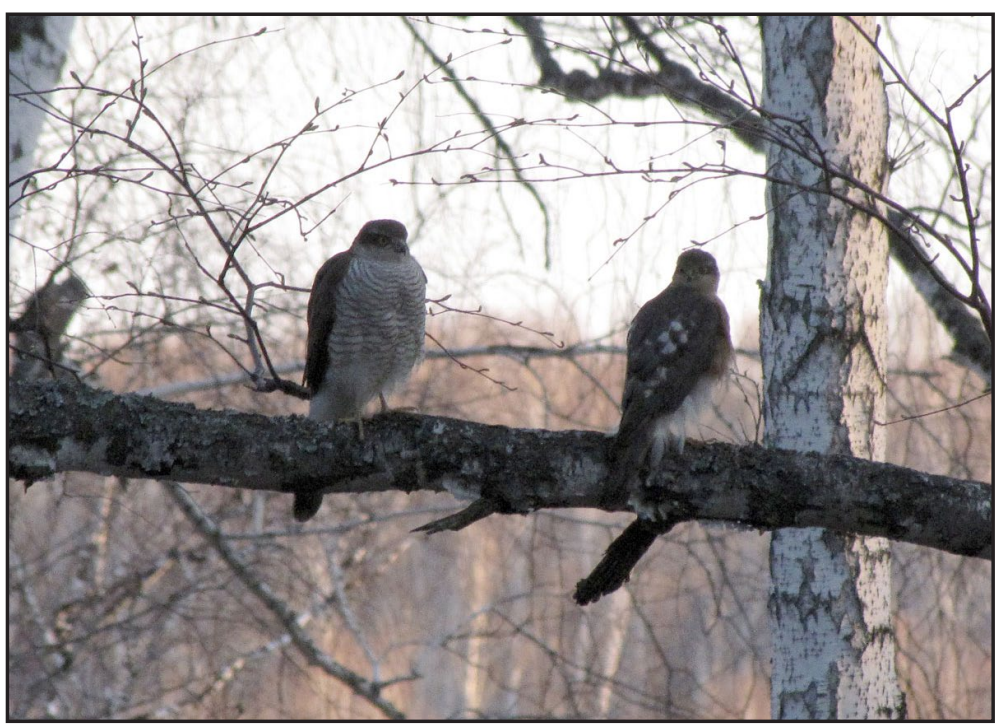

ся птицы. Взрослые птицы были встречены

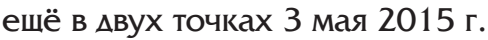

Плотность распределения составила 2,96 (пар)/100 км² обшей плошахи по результатам учёта встреч, приравниваемых к территориальным, 3,81ос./100 км² обшей площахи по результатам учёта всех встреченных птиц.

Обыкновенный канюк (Buteo buteo). Второй по численности после коршуна гнездяшийся вид бассейна Издревой.

Во время учётов 9 мая и 19 июля 2012 г. выявлено 5 гнездовых участков канюков с жилыми гнёздами и встречено 3 выводка, ешё в 5 точках встречены охотяшиеся птицы. Плотность распределения составима 5,50 (пар)/100 км² общей площади - по результатам учёта встреч, приравниваемых к территориаиьным, и 8,88 ос./100 км² обшей плошахи - по результатам учёта всех встреченных птиц.

Взрослые птицы были встречены также 3 мая 2015 г. и 10 июля 2016 г.

Гнездовые территории (как гнёзда, так и

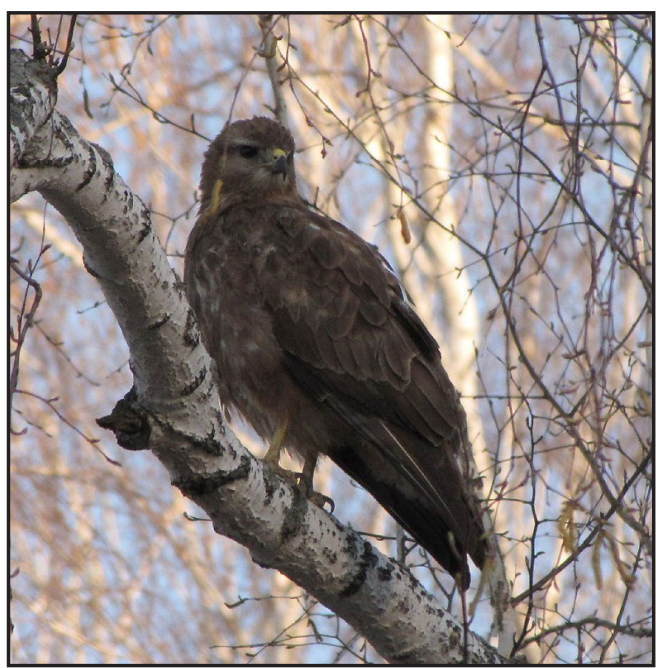

Пара перепелятников (Accipiter nisus). Фото И. Карякина.

Pair of the Eurasian Sparrowhawk (Accipiter nisus). Photo by I. Karyakin.

встречи птиц) приурочены к водоразделам и верховьям небольших притоков Изаревой. Только одна встреча взрослой птицы 10.07.2016 г. произошла около железной Аороги, вблизи СНТ "Аубрава".

\section{Семейство Соколиные Falconidae}

Чеглок (Falco subbuteo). Редкий, вероятно гнездяшийся виА.

ОАиночные птицы встречены в верховьях р. Изаревая 19 июля 2012 г. и в устье Изаревой 12 июля 2015 г. Также чеглок наблюдался 01.09.2016 г. в пойме Ини в 6,2 км от устья Изаревой вверх по реке (Сухов, 2016а). Выше. . Изаревой по р. Иня чеглок в норме гнездится в террасных борах.

Обыкновенная пустельга (Falco tinnunculus). РеАкий, вероятно гнездяшийся вид.

ОАиночные птицы встречены в 3-х точках в верховьях р. Издревая в 2012 г. П^отность распределения птиц составила 1,27 ос./100 км² обшей плошами. Аве пустельги на дистанции в 1 км одна от $А р у-$ гой наблюдамись 03.05.2015 г. в верховье Токаиихи. Также 13.08.2016 г. пустельга сфотограсрирована на р. Иня, в 6,2 км от устья Изаревой (Сухов, 2016b).

В верхней части бассейна и в самых низовьях р. Изаревая в районе А. Изаревая на территориях с ведушейся сельскохозяйственной деятельностью актуальны биотехнические мероприятия мля привлечения вила на размножение в искусственные гнездовья.

\section{Отряд Совообразные Strigiformes Семейство Совинье Strigidae}

В бассейне Изаревой встречено 3 вида сов, мля Авух из которых установлено гнезАование.

Болотная сова (Asio flammeus). Немногочисленный, вероятно гнезАяшийся виА, приуроченный к лугам, гАе гнездится на земие. В ночь с 18 на 19 июля 2012 г. совы встречены в 3-х точках на маршруте, протяжённостью 18,49 км по Аороге, илушей среди заброшенных сельхозугодий по вос-

Канюк (Buteo buteo). Фото И. Карякина. Common Buzzard (Buteo buteo). Photo by I. Karyakin. 

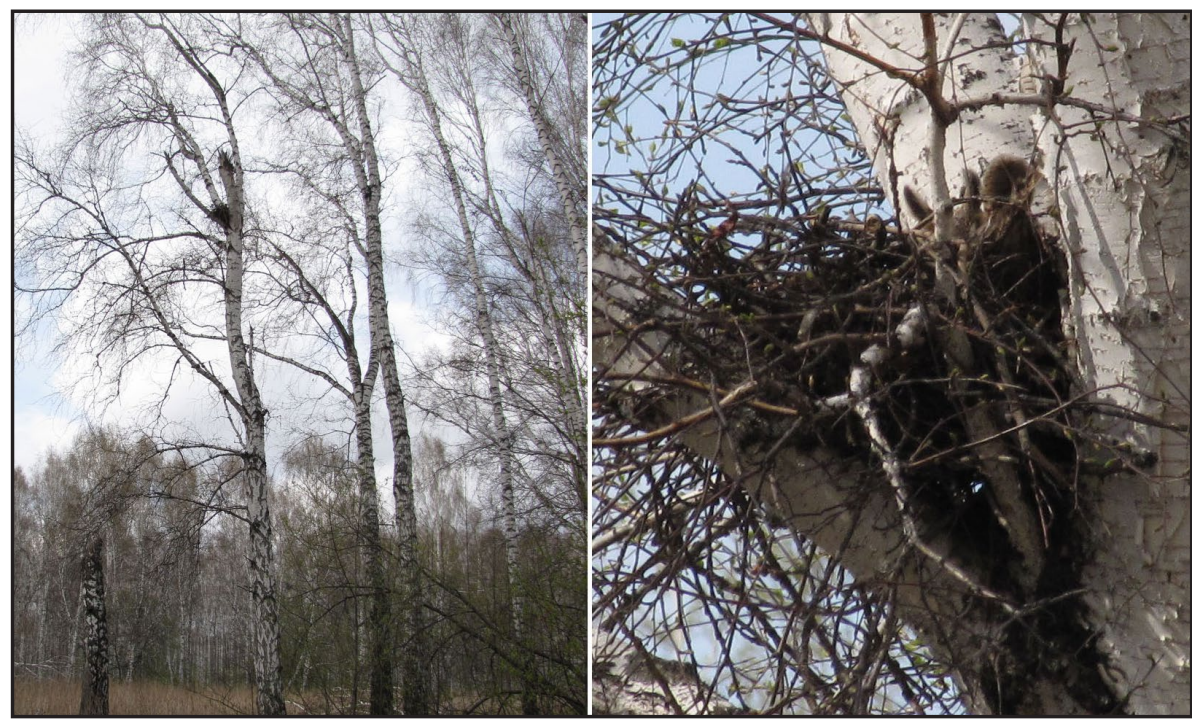

неясыти на размножении в искусственных гнездовьях на плошалке в бассейне Издревой выросла с 4-х гнездящихся пар в 2013 г. (следуюший гоА после установки первых совятников) АО 8 гнездяшихся пар в 2016 г. В 2016 г. Аистанции межАу жилыми гнёздами Аииннохвостой неясыти в совятниках варьировала в пределах 1,64-6,25 км, составив в среднем $(n=7) 2,75 \pm 1,64$ км.

\section{Угрозы и меры охраны}

Из наиболее распространённых угроз, выявленных в бассейне Изаревой мля пер-

Ушастая сова (Asio otus) в гнезде. Фото И. Карякина.

Long-Eared Owl (Asio otus) in the nest. Photo by I. Karyakin. точной границе бассейна Издревой. Обимие сов составило 1,62 ос./10 км маршрута.

Ушастая сова (Asio otus). Немногочисленный гнездяшийся вид лесных местообитаний. Узкоспециамизированный на питании серыми полёвками (Microtus sp.) вид, от Аинамики численности которых зависит его численность.

Обнаружено единственное гнездо с насиживаюшей птицей на краю лесного массива по р. Мал. Изаревая 8 мая 2012 г. и встречено 2 особи в $А$ вух разных точках 18 июля 2012 и 2015 гг. Плотность распределения по учёту в опушечной зоне составила 5,56 пар/100 км². Учёт выводков по голосам не Аал положительных результатов ни в 2012, ни в 2015 гг.

В верхней части бассейна и в самых низовьях р. Изаревая в районе А. Изаревая на территориях с ведушейся сельскохозяйственной деятельностью актуальны биотехнические мероприятия мия привлечения вила на размножение в искусственные гнездовья.

Мииннохвостая неясыть (Strix uralensis). Немногочисленный гнездяшийся вид, численность которого стала расти только после реализации мероприятий, по привлечению сов на размножение в искусственные гнездовья.

В 2012 г. в ходе целевого обследования территории на предмет обитания мииннохвостой неясыти встречена единственная птица на водоразделе в верховьях ИзАревой близ п. Барлакский, также присаха Аругой совы обнаружена в лесном массиве на левом берегу р. Токамиха в 1,6 км от р. Иня.

Благодаря проводимым с 2012 г. биотехническим мероприятиям (см. статью на стр. 27), численность Аииннохвостой натых хишников, можно отметить следуюшие:

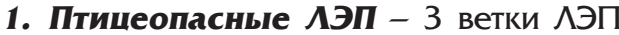
10-35 кВ со штыревыми изоляторами, на которых весьма вероятна гибель хишных птиц в результате поражения электротоком.

2. Нелегамьные рубки - ведутся вокруг всех СНТ и посёлков, в т.ч. на участках хишных птиц, что сокрашает фонд гнезАопригодных деревьев, а в гнездовой период приводит к гибели потомства. Рубки происходят на большой территории бассейна, к счастью, точечно.

\section{3. Нелегальное строительство дамб -} уничтожает кормовые биотопы хишников - узкие луговины по Аолинам ручьёв, обеспечиваюших пернатых хишников мышевидными грызунами.

\section{4. Проектируемое строительство му-} соросортировочного комбината с полигоном ТКО. В зоне любого полигона TKO, гАе есть открытые участки мля сортировки мусора, происходит концентрация врановых птиц. КогАа их много, они сами начинают оказывать пресс на пернатых хишников, и в этом случае им не могут противостоять Ааже такие виды, в норме добываюшие их мия пропитания, как ястреб-тетеревятник и Аииннохвостая неясыть. В результате, в 6-километровой зоне от мусоросортировочных комплексов все нативные виды хишников исчезают, остаётся только чёрный коршун, как более пластичный, который сушественно нарашивает численность. Это наблюдается на обеих соседних с бассейном Издревой свалках близ населённых пунктов Раздольное и Кольцово. Особенно страдают совы, которых в зимний период в ночное время привлекают скопления грызунов и врановых, 


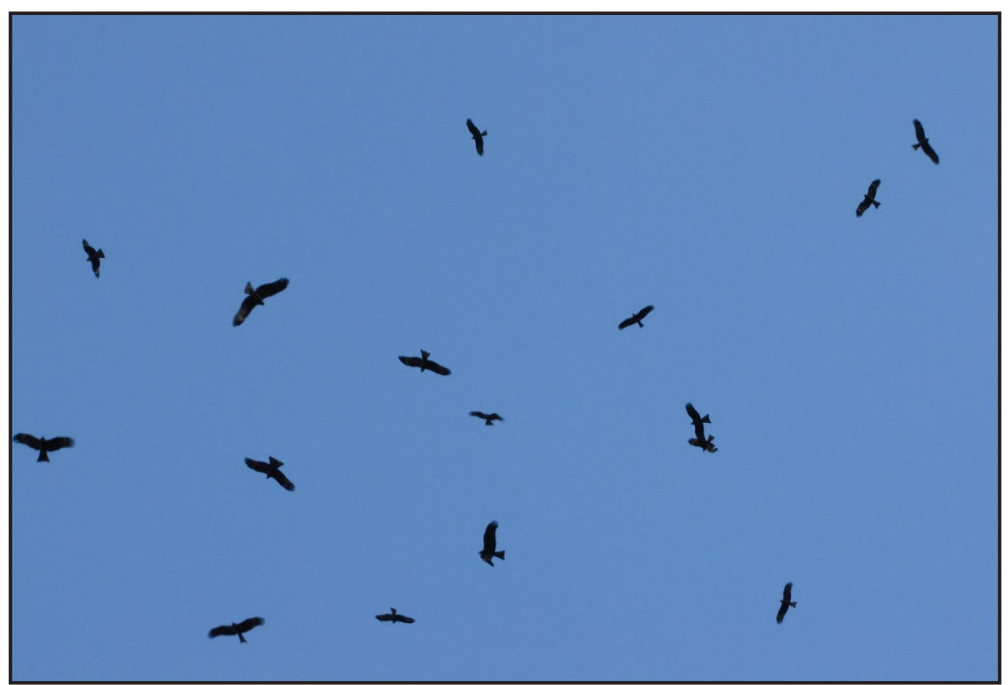

формируюшиеся у свалок, но в Аневное время организованные стаи врановых из неСкольких Аесятков особей способны убивать сов. В 6-километровую зону влияния вокруг планируюшегося МСК попахает также сушествуюший памятник природы "Аолина реки Издревая" и киастер "Токаиихинский лес" проектируемой ООПТ, которые могут потерять свою ценность Амя обитания ряла видов хишных птиц после запуска МСК.

Территория бассейна р. Издревая характеризуется нарушенным фраунистическим комплексом хишных птиц, из которого полностью выпали или выпадают все узкоспециализированные виды-энтомофаги (осоед обыкновенный Pernis apivorus, сплюшка Otus scops, кобчик Falco veapertinus), виды Ауплогнёздники (сычи Aegolius funereus, Glaucidium passerinum), миосраги, специамизируюшиеся на Аобыче видов-жертв в условиях невысокого травостоя (куни, пустельга), крайне низка численность специализированных миосрагов (ушастая сова) и орнитосрагов (тетеревятник, перепелятник), в питании которых важнейшую роль играет кишь один-два вида доминанта. Сушествование и рост гнезАовой группировки Аминнохвостой неясыти подцерживается в результате реализации биотехнических мероприятий.

Определённо, что такая ситуация в бассейне р. Издревая сложилась из-за ммительного влияния целого ряда факторов, под воздействием которых комплекс нативных видов Аеградировал, но Аругие виды, с более широким требованиям к кормовой базе, охотничьим и гнездовым биотопам (например, канюк) адаптироваАись к постоянному вАиянию одних и тех же факторов, а другие (коршун) даже стами извлекать из них пользу и сушественно
Скопление коршунов на сваике близ с. Раздольное. Фото И. Карякина.

Concentration of the Black Kites in a landfill near Razdolnoe. Photo by I. Karyakin.

увеличили локаиьную численность. В свете этого бассейн ИзАревой можно считать универсальным полигоном, мяя изучения взаимного влияния жизнедеятельности человека и хишных птиц, а также мия реализации программ по восстановлению численности пернатых хишников в условиях разнонаправленной антропогенной нагрузки,

В настояшее время одними из приоритетных направлений мля восстановления численности хишных птиц в бассейне ИзАревой являются:

- отказ от строительства мусоросортировочного комплекса с полигоном ТКО;

- создание спроектированных ООПТ;

- нейтраиизация постоянных негативных факторов, таких как гибель на АЭП в результате поражения электротоком;

- устранение кимитируюших сракторов, таких как недостаток гнездового фонда, и продолжение биотехнических мероприятий, направленных на привлечение пернатых хишников на размножение в искусственные гнезАовья.

\section{Литература}

Заева В. Полевой мунь Circus cyaneus (Linnaeus, 1766) Hen Harrier. г. Новосибирск, с. Гусиный брод. 2016-05-02. - Птицы Сибири. 2016. [Zaeva V. Hen Harrier Circus cyaneus (Linnaeus, 1766). Novosibirsk city, Gusiniy Brod vill. 2016-05-02. - Siberian Birdwatching Community. 2016]. URL: http://sibirds.ru/v2photo. php?l=ru\&s=055700002\&n=1 Аата обрашения: 30.03.2017.

Сухов И. Чеглок Falco subbuteo (Linnaeus, 1758) Eurasian Hobby. Новосибирская область, Шелковичиха. 2016-09-01. - Птицы Сибири. 2016a. [Sukhov I. Eurasian Hobby Falco subbuteo (Linnaeus, 1758). Novosibirsk region, Shelkovichikha. 2016-09-01. - Siberian Birdwatching Community. 2016a]. URL: http://sibirds.ru/ v2photo.php?s=062500094\& $=$ ru\& $n=1 \quad$ Аата обрашения: 30.03.2017.

Сухов И. Обыкновенная пустельга Falco tinnunculus (Linnaeus, 1758) Common Kestrel. Новосибирская область, Шелковичиха. 201608-13. - Птицы Сибири. 2016b. [Sukhov I. Common Kestrel Falco tinnunculus (Linnaeus, 1758). Novosibirsk region, Shelkovichikha. 2016-08-13. - Siberian Birdwatching Community. 2016b]. URL: http://sibirds.ru/v2photo. php?s=062500027\&l=ru\&n=1 Аата обрашения: 30.03.2017. 